\title{
Research of Multi-axis NC Machining Method of Cylindrical Cam Based on UG NX
}

\author{
Qianhua Liang \\ Electro-machinery Engineering Department, Chengdu Industrial Vocational Technical College, Sichuan, China \\ Corresponding author:86755232@qq.com
}

\begin{abstract}
We have focused significant efforts on developing solutions for precision machining of cylindrical cams based on UG NX. A variety of processing method are put forward according to the digital model for a cylindrical cam which has been derived through parametric design, all of which are made a detailed comparison, analysis, research, elaborated. Simulation processing, post processing and NC program are carried out though optimized processing scheme. It will provide a reference for the numerical control programming of four-Coordinated axis.
\end{abstract}

\section{Introduction}

Cylindrical CAM is a cylinder on fluted artifacts, when moves, by higher pair contact follower can get according to the law of change of reciprocating motion [1]. Cylindrical CAM because of its small size, compact structure, high torque and rotational speed, etc. is widely used in the packaging, textile, food and pharmaceutical machinery automation $[2,3]$. Because of cylindrical CAM profile curve is a closed space curve, with the traditional method is difficult to obtain accurate contour data so as to meet the needs of the CNC programming, it brings to the processing and manufacturing huge difficulties [4].

Using UG NX cylindrical CAM three-dimensional entity model is set up, and avoids the complex C language or other engineering software secondary development programming processing, make the CAM contour design is both accurate and simple $[5,6,7]$. At the same time, the use of UG processing module for CAM groove tool path is simulated, and through post-processing generate nc program can be used for machining center.

Through the technology analysis, the cylindrical CAM with four axis of A shaft is suitable for machining center. Generate four axis of cylindrical CAM slot method of tool path is very much, in this paper, by comparing, optimizing the reasonable solution.

\section{Modeling}

\subsection{Parameter equation for cylindrical CAM}

According to the principle of mechanical knowledge [8], cylindrical CAM contour curve parameter equation for (1), in which

$x, y, z$ - curve on arbitrary point coordinates

$s$ - follower motion

$r_{0}$ - said base circle radius

$j$ - said the CAM Angle

$$
\left\{\begin{array}{l}
x=r_{0} \cos j \\
y=r_{0} \sin j \quad\left(0^{\circ} \leq j \leq 360^{\circ}\right) \\
z=s(j)
\end{array}\right.
$$

\subsection{Parameters}

Stroke cylinder radius $=30 \mathrm{~mm}$

follower $\mathrm{h}=20 \mathrm{~mm}$

(C) The Authors, published by EDP Sciences. This is an open access article distributed under the terms of the Creative Commons Attribution License 4.0 (http://creativecommons.org/licenses/by/4.0/). 
curved groove $b=12 \mathrm{~mm}$ wide

groove depth $=7 \mathrm{~mm}$

motion angle for rise travel $=120^{\circ}$

farthest dwell angle $=60^{\circ}$

motion angle for return travel $=120^{\circ}$

nearest dwell angle $=60^{\circ}$

both the rise travel and the return travel of the follower are follow simple harmonic motion.

\subsection{CAM expression of UG}

Design of CAM contour curve based on the above conditions, paragraphs $U$ G expressions such as table 1. It is important to note:

(1) $t$, as UG system variables, $0 \leqslant t \leqslant 1[9]$.

(2) the working curve generated by rule curve respectively, and pasted to another file, each group of the curve and the graph object parameters $(\mathrm{xt}, \mathrm{yt}, \mathrm{zt})$.

\subsection{D model}

Generate the contour curve is shown in figure 1. Generate $\varphi 60 \mathrm{~mm}$ columns as shown in figure 2. To draw on in cylindrical center line of plane cross section sketch, drawing size to reflect slot width and groove depth, here to pay attention to the section size must be greater than the groove depth. With the method of differential scanning o generated CAM slot, pay attention to when scanning, cross section determination of locating method to $\varphi 60 \mathrm{~mm}$ for reference, the cylinder is direction to "plane normal", get the required CAM as shown in figure 4.

Table 1. U G expression for paragraphs of contour curve.

\begin{tabular}{|c|c|c|c|}
\hline Name & Formula & unit & note \\
\hline a1 & 120 & degree & $\begin{array}{l}\text { motion angle for } \\
\text { rise travel }\end{array}$ \\
\hline $\mathrm{a} 2$ & 60 & degree & $\begin{array}{l}\text { farthest dwell } \\
\text { angle }\end{array}$ \\
\hline a3 & 120 & degree & $\begin{array}{l}\text { motion angle for } \\
\text { return travel }\end{array}$ \\
\hline a4 & 60 & degree & nearest dwell angle \\
\hline $\mathrm{h}$ & 20 & degree & Follower trip \\
\hline j1 & $\mathrm{a} 1 *_{\mathrm{t}}$ & degree & $\begin{array}{l}\text { angle variable for } \\
\text { rise }\end{array}$ \\
\hline $\mathrm{j} 2$ & $\mathrm{a} 1+\mathrm{a} 2 * \mathrm{t}$ & degree & $\begin{array}{l}\text { angle variable } \\
\text { for farthest dwell }\end{array}$ \\
\hline j3 & $\mathrm{a} 1+\mathrm{a} 2+\mathrm{a} 3 * \mathrm{t}$ & degree & $\begin{array}{l}\text { angle variable } \\
\text { for return }\end{array}$ \\
\hline $\mathrm{j} 4$ & $\mathrm{a} 1+\mathrm{a} 2+\mathrm{a} 3+\mathrm{a} 4 * \mathrm{t}$ & degree & $\begin{array}{l}\text { angle variable for } \\
\text { nearest dwell }\end{array}$ \\
\hline $\mathrm{r} 0$ & 30 & $\mathrm{~mm}$ & cylinder radius \\
\hline s1 & $\begin{array}{c}(\mathrm{h} / 2)^{*}(1- \\
\cos (180 * \mathrm{t}))\end{array}$ & $\mathrm{mm}$ & variable for rise \\
\hline s2 & $\mathrm{h}$ & $\mathrm{mm}$ & farthest trip \\
\hline s3 & $\begin{array}{c}(\mathrm{h} / 2) *(1+ \\
\cos (180 * \mathrm{t}))\end{array}$ & $\mathrm{mm}$ & variable for return \\
\hline s4 & 0 & $\mathrm{~mm}$ & nearest trip \\
\hline
\end{tabular}




\begin{tabular}{|c|c|c|c|}
\hline $\mathrm{t}$ & 0 & & $\begin{array}{l}\text { system variable } \\
\text { (constant) }\end{array}$ \\
\hline $\mathrm{xt} 1$ & $(\mathrm{r} 0+\mathrm{s} 1) * \cos (\mathrm{j} 1)$ & $\mathrm{mm}$ & $\begin{array}{c}\text { coordinate } \\
\text { variables of } \mathrm{x} \text { for } \\
\text { rise }\end{array}$ \\
\hline $\mathrm{xt} 2$ & $(\mathrm{r} 0+\mathrm{s} 2) * \cos (\mathrm{j} 2)$ & $\mathrm{mm}$ & $\begin{array}{c}\text { coordinate } \\
\text { variables of } \mathrm{x} \text { for } \\
\text { farthest dwell }\end{array}$ \\
\hline $\mathrm{xt} 3$ & $(\mathrm{r} 0+\mathrm{s} 3) * \cos (\mathrm{j} 3)$ & $\mathrm{mm}$ & $\begin{array}{l}\text { coordinate } \\
\text { variables of } x \text { for } \\
\text { return }\end{array}$ \\
\hline $\mathrm{xt} 4$ & $(\mathrm{r} 0+\mathrm{s} 4) * \cos (\mathrm{j} 4)$ & $\mathrm{mm}$ & $\begin{array}{c}\text { coordinate } \\
\text { variables of } x \text { for } \\
\text { nearest dwell }\end{array}$ \\
\hline yt1 & $(\mathrm{r} 0+\mathrm{s} 1) * \sin (\mathrm{j} 1)$ & $\mathrm{mm}$ & $\begin{array}{c}\text { coordinate } \\
\text { variables of y for } \\
\text { rise }\end{array}$ \\
\hline yt2 & $(\mathrm{r} 0+\mathrm{s} 2)^{*} \sin (\mathrm{j} 2)$ & $\mathrm{mm}$ & $\begin{array}{c}\text { coordinate } \\
\text { variables of y for } \\
\text { farthest dwell }\end{array}$ \\
\hline yt3 & $(\mathrm{r} 0+\mathrm{s} 3)^{*} \sin (\mathrm{j} 3)$ & $\mathrm{mm}$ & $\begin{array}{c}\text { coordinate } \\
\text { variables of y for } \\
\text { return }\end{array}$ \\
\hline yt4 & $(\mathrm{r} 0+\mathrm{s} 4)^{*} \sin (\mathrm{j} 4)$ & $\mathrm{mm}$ & $\begin{array}{c}\text { coordinate } \\
\text { variables of y for } \\
\text { nearest dwell }\end{array}$ \\
\hline zt1 & s1 & $\mathrm{mm}$ & $\begin{array}{l}\text { coordinate } \\
\text { variables of } \mathrm{z} \text { for } \\
\text { rise }\end{array}$ \\
\hline $\mathrm{zt} 2$ & $\mathrm{~s} 2$ & $\mathrm{~mm}$ & $\begin{array}{c}\text { coordinate } \\
\text { variables of } \mathrm{z} \text { for } \\
\text { farthest dwell }\end{array}$ \\
\hline $\mathrm{zt} 3$ & s3 & $\mathrm{mm}$ & $\begin{array}{c}\text { coordinate } \\
\text { variables of } \mathrm{z} \text { for } \\
\text { return }\end{array}$ \\
\hline zt4 & s4 & $\mathrm{mm}$ & $\begin{array}{c}\text { coordinate } \\
\text { variables of } \mathrm{z} \text { for } \\
\text { nearest dwell }\end{array}$ \\
\hline
\end{tabular}

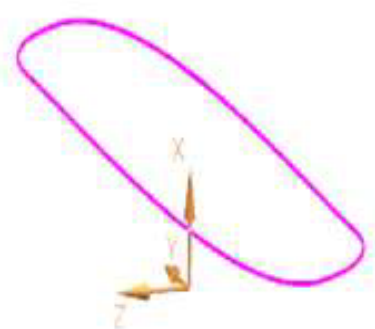

Fig. 1. Control curv. 


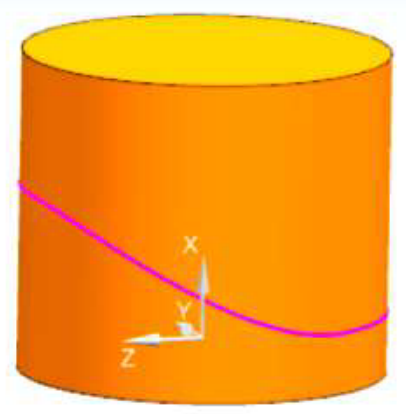

Fig. 2. Base circle cylinder.

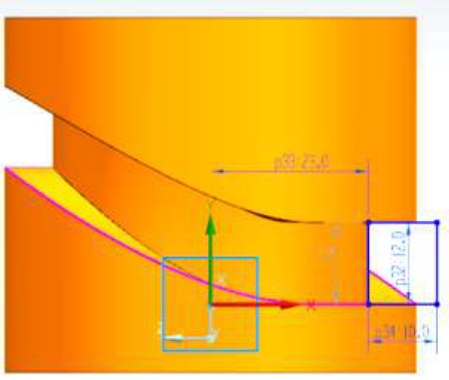

Fig. 3. Sketching of cam path.

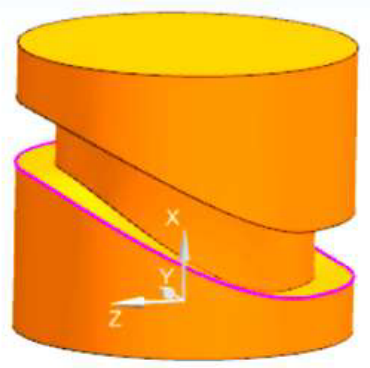

Fig. 4. Cylinder CAM.

\section{CAM 4 axis machining of cylinder CAM}

\subsection{Machining of the Underside}

Choose the first method. The need when using this method on the CAM groove bottom cylinder offset groove bottom CAM contour curve. Offset method is very simple, only can be produced to a command. Because processing is the bottom of the channel surface, thus can choose the bottom of the channel for cylinder part geometry. This method is safe and fast generated dao road. The rest of the way to do auxiliary plane and line, and reach cut but need to adjust the parameters. When machining CAM groove bottom also note that because use tool blanket out of the groove width, to generate tool path after must pay attention to check, especially when cutting, turning points in driving curve will cut, such as cutting, can move in non cutting parameters will be set as slotting cutting way. To generate tool path is shown in figure 5 .

Table 2. Underside machining method comparison.

\begin{tabular}{|c|c|c|c|c|}
\hline No. & $\begin{array}{c}\text { drive } \\
\text { method }\end{array}$ & $\begin{array}{c}\text { Projection } \\
\text { Vector }\end{array}$ & Shaft & note \\
\hline
\end{tabular}




\begin{tabular}{|c|c|c|c|c|}
\hline 1 & $\begin{array}{c}\text { Curve/ } \\
\text { point }\end{array}$ & Shaft & $\begin{array}{c}\text { Away from the } \\
\text { straight line }\end{array}$ & $\begin{array}{c}\text { Need to choose the } \\
\text { appropriate tool by } \\
\text { one cut }\end{array}$ \\
\hline 3 & $\begin{array}{c}\text { Curve/ } \\
\text { point }\end{array}$ & $\begin{array}{c}\text { Toward the } \\
\text { straight line }\end{array}$ & $\begin{array}{c}\text { Perpendicular to } \\
\text { the parts }\end{array}$ & $\begin{array}{c}\text { Need to choose the } \\
\text { appropriate tool by } \\
\text { one cut }\end{array}$ \\
\hline 4 & streamline & $\begin{array}{c}\text { Toward the } \\
\text { straight line }\end{array}$ & $\begin{array}{c}\text { Away from the } \\
\text { straight line }\end{array}$ & $\begin{array}{c}\text { Need to make } \\
\text { auxiliary plane } \\
\text { according to the } \\
\text { cutting tool }\end{array}$ \\
\hline streamline & $\begin{array}{c}\text { Toward the } \\
\text { straight line }\end{array}$ & $\begin{array}{c}\text { Perpendicular to } \\
\text { the parts }\end{array}$ & $\begin{array}{c}\text { Need to make } \\
\text { auxiliary plane } \\
\text { according to the } \\
\text { cutting tool }\end{array}$ \\
\hline
\end{tabular}

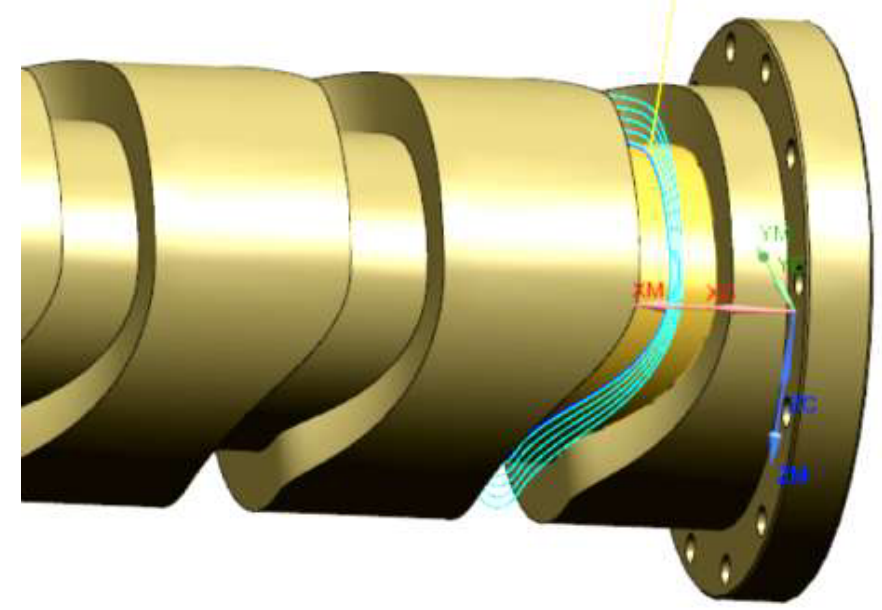

Fig. 5. Tool path of the Underside.

\subsection{Machining of the side}

Table 3. Side machining method comparison.

\begin{tabular}{|c|c|c|c|c|}
\hline No. & $\begin{array}{c}\text { drive } \\
\text { method }\end{array}$ & $\begin{array}{c}\text { Projection } \\
\text { Vector }\end{array}$ & Shaft & note \\
\hline 1 & Curve/point & shaft & $\begin{array}{c}\text { Away from the } \\
\text { straight line } \\
\text { more tool path by } \\
\text { cutting parameters, } \\
\text { can be offset }\end{array}$ \\
\hline 2 & Curve/point & $\begin{array}{c}\text { Toward the } \\
\text { straight line }\end{array}$ & $\begin{array}{c}\text { Perpendicular to } \\
\text { the parts }\end{array}$ & $\begin{array}{c}\text { more Tool path by } \\
\text { cutting parameters, } \\
\text { can be offset }\end{array}$ \\
\hline
\end{tabular}




\begin{tabular}{|c|c|c|c|c|}
\hline 3 & streamline & $\begin{array}{c}\text { Perpendicular to } \\
\text { the driver }\end{array}$ & $\begin{array}{c}\text { Away from the } \\
\text { straight line }\end{array}$ & $\begin{array}{c}\text { Need to make } \\
\text { auxiliary plane } \\
\text { according to the } \\
\text { cutting tool }\end{array}$ \\
\hline 4 & surface & $\begin{array}{c}\text { Perpendicular to } \\
\text { the driver }\end{array}$ & $\begin{array}{c}\text { Away from the } \\
\text { straight line }\end{array}$ & $\begin{array}{c}\text { Need to analyze } \\
\text { surface UV } \\
\text { direction }\end{array}$ \\
\hline 5 & surface & $\begin{array}{c}\text { Perpendicular to } \\
\text { the driver }\end{array}$ & side edge driver & $\begin{array}{c}\text { Need to analyze } \\
\text { surface UV } \\
\text { direction }\end{array}$ \\
\hline
\end{tabular}

First methods are preferred. When the method is adopted, the bottom cam profile curve of the bottom of the cam groove is needed, and the workpiece geometry can also be selected. This method is safe and fast. The remaining methods need to do the auxiliary surface and the line, and need to adjust the parameters to achieve but cut. In general, in the four axis machining, the cutter shaft is preferred to use far away from the straight line. Generate the tool path as shown in the following figure:

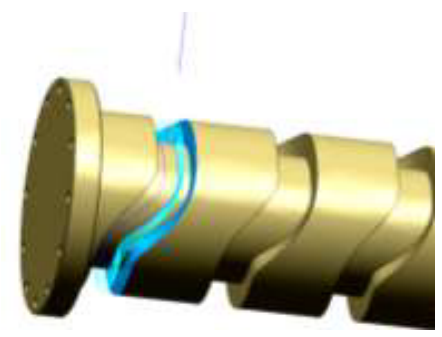

Fig. 6. Tool path of the side.

\section{3 clean-up machining}

Table 4. Clean-up machining method comparison.

\begin{tabular}{|c|c|c|c|c|}
\hline No. & $\begin{array}{c}\text { drive } \\
\text { method }\end{array}$ & $\begin{array}{l}\text { Projection } \\
\text { Vector }\end{array}$ & Shaft & note \\
\hline 1 & Curve/point & shaft & $\begin{array}{l}\text { Away from the } \\
\text { straight line }\end{array}$ & $\begin{array}{l}\text { Need to choose the } \\
\text { appropriate tool by } \\
\text { one cut }\end{array}$ \\
\hline 2 & Curve/point & $\begin{array}{l}\text { Toward the } \\
\text { straight line }\end{array}$ & $\begin{array}{c}4 \text { axis, } \\
\text { Perpendicular to } \\
\text { the parts }\end{array}$ & $\begin{array}{l}\text { Need to choose the } \\
\text { appropriate tool by } \\
\text { one cut }\end{array}$ \\
\hline 3 & surface & $\begin{array}{c}\text { Toward the } \\
\text { driver }\end{array}$ & $\begin{array}{l}\text { Away from the } \\
\text { straight line }\end{array}$ & $\begin{array}{l}\text { Need to modify the } \\
\text { driving parameters }\end{array}$ \\
\hline
\end{tabular}

Choose the first method for the CAM groove side finishing machining, at the bottom of the finish machining by changes in rough machining method based on the corresponding parameters. The third method is commonly used, but need to choose the CAM groove profile as driving surfaces and components, projection vector selection toward the driver. If appear beat phenomenon in tool path generated by this method, the initial step length can be appropriately modified surface percentage and the end of the step length.

\section{Program generation}

On the basis of the tool path on UG own multi-axis reprocessing or post-processing can generate the corresponding $\mathrm{NC}$ system can use the processing program of. In machine cut using machine tools needed to view, after the clamping work piece can be generated by the program for processing simulation, observation program correctly or not [10]. After the 
confirmation process is correct, can through the network DNC, CF card and cable communication program into the corresponding machine tool can work out the parts [11].

\section{Summary}

Through the above examples can be seen that the UG software is very good to ensure the parts modeling accuracy, and provides a variety of simulation processing strategy, good maneuverability, generate NC program code and fast. At the same time, by contrast, found that for such four axis machining parts, drive method multi-select curve or surface drive, and try to use existing curve or surface parts, under the condition of the existing line or face can't meet to select new. If the tool path knife jumping, drive parameters can be appropriately adjusted to achieve the ideal effect. Away from the straight line option widely used knife shaft, linear choose cylindrical axis, fast accurate tool path.

\section{References}

1. Zheng wenwei, Wu. Edit. Mechanical principle. Beijing. Higher education press (1997).

2. machine design graphics manual. Chemical Industry Press (2004).

3. YuQing, rong-chang Liu etc. Spatial cylindrical CAM nc machining process design. Journal of mechanical design, 4 (2006) .

4. Yu-lin han. Full parameterized design of cylindrical CAM Model based on UG. Manufacturing technology and machine tool, 11 (2007).

5. Yang Ni, zheng-hao Ge, etc. Based on Pro/E design method for spatial cams and 3 D modeling. Journal of mechanical design, 12 (2007).

6. Huang Xinlin, ju-jiang Cao. The construction of a complex surface based on UG CAM contour surface. Journal of shaanxi university of science and technology, 11 (2004).

7. Ju-jiang Cao, Li Longgang etc. Based on UG NX6.0 globular indexing CAM 3 d entity modeling and simulation processing. mechanical design and manufacturing, 1 (2011).

8. Ya-hui Su., based on Pro/E of 4.0 cylindrical groove CAM parameterized design and simulation processing. Journal of coal mine machinery, 2 (2011).

9. Beijing trillion technology co., LTD. UG NX 8.5 bible. Beijing, China water conservancy and hydropower press (2013).

10. Beijing trillion technology co., LTD. UG NX 8.5 bible of Numerical control engineers. Beijing, China water conservancy and hydropower press (2013).

11. Geng GuoQing. Nc machine tool and computer serial port line connection and data transmission. Journal of machine tools and hydraulic, 14 (2012). 